\title{
Biologics in renal transplantation
}

\author{
Ryszard Grenda
}

Received: 18 April 2014 / Revised: 9 June 2014 / Accepted: 10 June 2014 / Published online: 26 July 2014

(C) The Author(s) 2014. This article is published with open access at Springerlink.com

\begin{abstract}
The biologics used in transplantation clinical practice include several monoclonal and polyclonal antibodies aimed at specific cellular receptors. The effect of their mechanisms of action includes depleting or blocking specific cell subpopulations, complement system, or removing circulating preformed antibodies and blocking their production. They are used in induction, desensitization ABO-incompatible renal transplantation, rescue therapy of steroid-resistant acute rejection, treatment of posttransplant recurrence of primary disease such as nephrotic syndrome or atypical hemolytic-uremic syndrome, and in late humoral rejection. There are various indications for the use of biologic agents before and early or late after renal transplantation in both high- and low-risk recipients. In the latter situation, the biologics-based induction is used to further minimize immunosuppression maintenance. The targets of several biologic agents are present across a variety of cells, and manipulation of the immune system with biologics may be associated with significant risk of acute and late-onset adverse events; therefore, clinical risk-versusbenefit ratio must be carefully balanced in every case. Several trials on novel biologics are reported in adults but not in the pediatric population.
\end{abstract}

Keywords Biologic drugs $\cdot$ Renal transplantation ·

Mechanisms $\cdot$ Indications $\cdot$ Safety

\section{Introduction}

Biologic agents used in renal transplantation include several drugs of different mechanisms of action, given intravenously,

R. Grenda $(\bowtie)$

Department of Nephrology \& Kidney Transplantation, The Childrens

Memorial Health Institute, Warsaw, Poland

e-mail: r.grenda@czd.pl aimed at blocking or depleting specific cell subpopulations or blocking circulating alloantibody responses or the complement system. From a clinical standpoint, they are used in induction, desensitization procedures in hyperimmunized patients, $\mathrm{ABO}-$ incompatible renal transplantation, treatment of steroid-resistant and/or humoral rejection, and therapy for recurrence of specific primary renal disease, such as nephrotic syndrome (NS) or atypical hemolytic uremic syndrome (aHUS) (Fig. 1). They are used before and early or late after renal transplantation in both high- and low-risk recipients (Fig. 2). Several biologic agents are used in clinical practice in pediatric renal transplantation; however, the majority is used off-label, and their dose range and optimal number of doses are not clearly defined. This review summarizes data on experience, efficacy, and safety of biologics used in renal transplantation in children and on emerging new agents, used only in adult practice or clinical trials, that have not yet been verified in the pediatric setting. Drugs used in children include monoclonal antibodies (MAb) daclizumab, basiliximab, and alemtuzumab; polyclonal antibodies thymoglobulin or ATGAM [lymphocyte immune globulin, antithymocyte globulin (equine) sterile solution], specific MAb such as rituximab and eculizumab; and human immunoglobulin preparations [intravenous immunoglobulins (IVIG)]. Targets for and mechanisms of action of these agents are presented in Table 1. Indications, duration of action, and specific monitoring are presented in Table $2[1-3,11-19$, $21-23,25-28,39,42-47,49,53,56,57,62-64]$. A variety of new drugs were investigated in several clinical trials that recruited adult renal graft recipients $[3,4]$. These new molecules were used to desensitize high-risk patients, in induction protocols, and to treat humoral rejection. Emerging new drugs and their specific targets in the immune system are listed in Table 3 [4]; clinical experience from clinical trials in adult patients is summarized in Table 4 [4-10], and evidence-based (EB) clinical experience in the pediatric population is presented in Table 5 [11-19, 21-23, 25-28, 33, 39, 42-47, 49, 53, 56, 57, 62-64]. 
Fig. 1 Indications to use biologics in renal transplantation

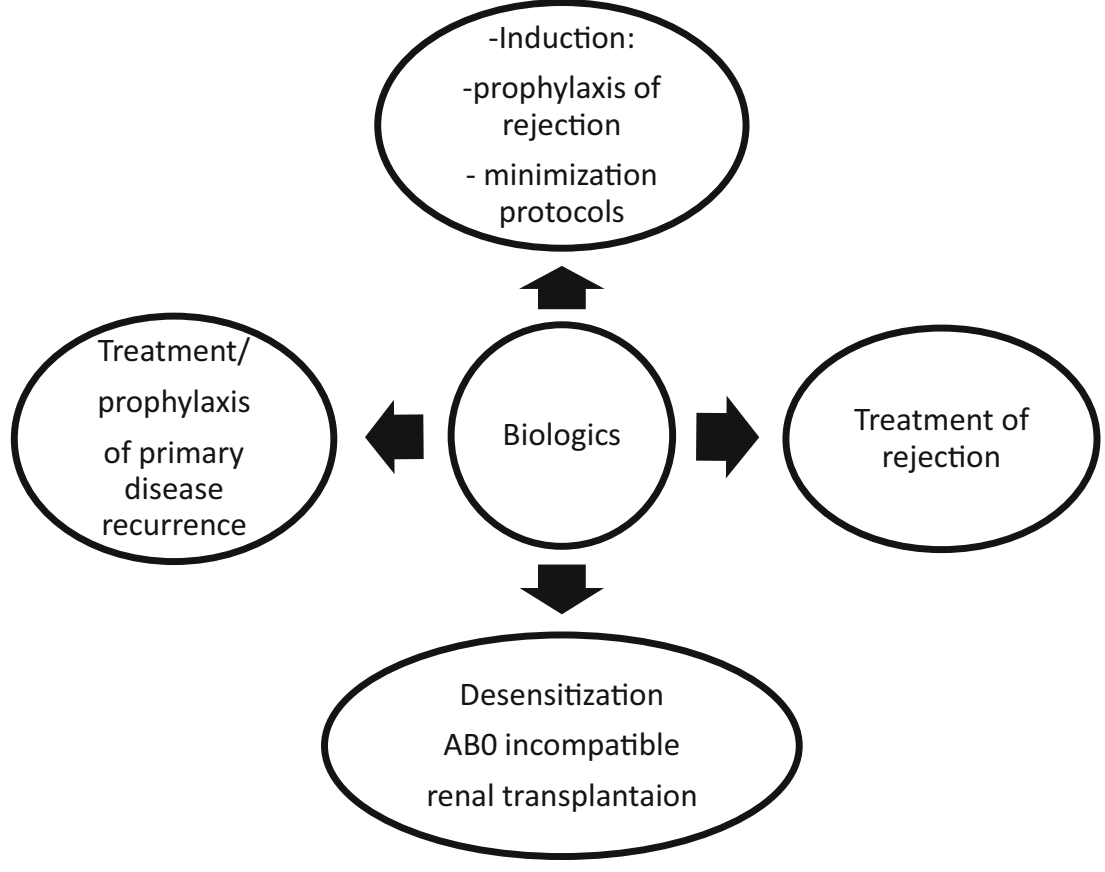

\section{Biologics in induction}

Induction is the most common indication to use biologic agents in pediatric renal graft recipients. It is used for two reasons: (1) to enhance the strength of initial triple immunosuppression in patients with high immunological risk [sensitized, retransplanted, poor human leukocyte antigen (HLA) matching or marginal donor transplant] or (2) to introduce minimization protocol aimed at reducing exposure to steroids or calcineurin inhibitors (CNI), or both. In the second indication, MAbs were used in patients with low immunological risk and polyclonal $\mathrm{Ab}$ in patients with low and high immunological risk.
MAb used in pediatric transplantation include anti-CD25 (IL-2R $\alpha$ ) inhibitors daclizumab and basiliximab and anti$\mathrm{CD} 52$-depleting $\mathrm{Ab}$ alemtuzumab used off label. The duration of effect (for two doses of basiliximab) expressed as receptor saturation was present at about 5 weeks with no mycophenolate mofetil (MMF) and about 10 weeks with concomitant MMF therapy [11]. In the Stanford steroid avoidance trial, the trough concentration of daclizumab was monitored by sequential sandwich enzyme-linked immunosorbent assay (ELISA); however, routinely, no specific monitoring is used in practice [12]. Comprehensive information on efficacy and safety of anti-CD25 inhibitors basiliximab and daclizumab, including in renal-graft recipients of different ages, comes

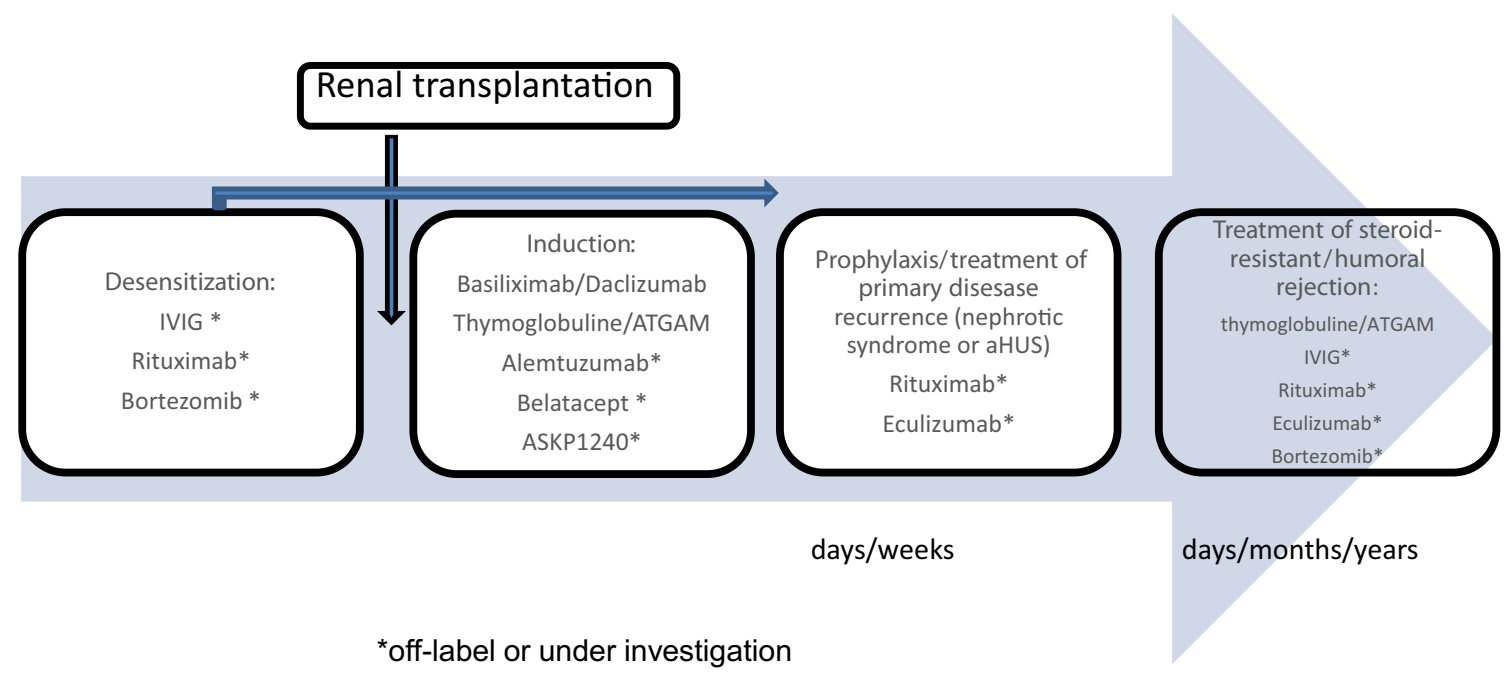

Fig. 2 Timing biologic use in renal transplantation 
Table 1 Biologic agents used in pediatric renal transplantation in clinical practice: targets in the immune system and mechanisms of action $[1,3]$
$M A b$ monoclonal antibody, ATGAM lymphocyte immune globulin, antithymocyte globulin (equine) sterile solution, $I V I G$ intravenous immunoglobulins, $I g G$ immunoglobulin G, $I L-2$ interleukin-2, $A P C$ antigen-presenting cells, HLA human leukocyte antigen, $N K$ natural killer

\begin{tabular}{|c|c|c|}
\hline Agent & Target & Suggested mechanism of action \\
\hline $\begin{array}{l}\text { Daclizumab (humanized } \\
\text { MAb), basiliximab } \\
\text { (chimeric MAb) }\end{array}$ & $\begin{array}{l}\text { CD25 } \\
\quad \text { (IL-2 receptor } \alpha \text { chain) }\end{array}$ & $\begin{array}{l}\text { Binds to and blocks IL-2 receptor on T cells, } \\
\text { inhibiting IL-2-induced T-cell activation }\end{array}$ \\
\hline $\begin{array}{l}\text { Alemtuzumab } \\
\text { (humanized MAb) }\end{array}$ & CD52 & $\begin{array}{l}\text { Binds to CD52 receptor on T and B cells, } \\
\text { monocytes, macrophages, and NK cells, } \\
\text { resulting cell lysis and long-lasting depletion }\end{array}$ \\
\hline Rituximab (chimeric MAb) & $\mathrm{CD} 20$ & $\begin{array}{l}\text { Binds to CD20 on B cells and mediates B-cell } \\
\text { lysis and depletion }\end{array}$ \\
\hline $\begin{array}{l}\text { Eculizumab (recombinant } \\
\text { humanized MAb) }\end{array}$ & Complement protein $\mathrm{C} 5$ & $\begin{array}{l}\text { Binds to complement protein } \mathrm{C} 5 \text {, inhibiting } \\
\text { its cleavage to } \mathrm{C} 5 \mathrm{a} \text { and } \mathrm{C} 5 \mathrm{~b} \text { and } \\
\text { preventing generation of terminal } \\
\text { complement complex } \mathrm{C} 5 \mathrm{~b}-9\end{array}$ \\
\hline $\begin{array}{l}\text { Thymoglobulin/ATGAM } \\
\text { (polyclonal IgG) }\end{array}$ & $\begin{array}{l}\text { T cells: CD3, CD4, CD8, } \\
\text { CD58, CD28 and others } \\
\text { B cells: CD5, CD58, CD28, } \\
\text { CD152 and others } \\
\text { APC: HLA-DR, CD58, } \\
\text { CD80, CD86, CD40 } \\
\text { and others } \\
\text { Several receptors present on } \\
\text { plasma cells, monocytes, } \\
\text { dendritic cells, leucocytes, } \\
\text { and others }\end{array}$ & $\begin{array}{l}\text { Blocks several T- and B-cell receptors, } \\
\text { causing cell dysfunction, lysis, } \\
\text { and long-lasting depletion }\end{array}$ \\
\hline $\begin{array}{l}\text { IVIG (polyclonal } \\
\text { human IgG) }\end{array}$ & $\begin{array}{l}\text { Circulating alloantibodies } \\
\text { and B cells }\end{array}$ & $\begin{array}{l}\text { Related to antibody and B cells } \\
\text { (selected mechanisms): } \\
\text { Anti-idiotypic blockade of alloantibodies } \\
\text { Downregulation of Ab production } \\
\text { Increased catabolism of IgG caspase and } \\
\text { mitochondrial-induced apoptosis of B cells }\end{array}$ \\
\hline
\end{tabular}

from a Cochrane database large systematic review involving 71 adult and pediatric trials and 10,520 participants. Use of both daclizumab and basiliximab given in induction decreased the risk of acute rejection in the first year after transplantation by $25 \%$ [relative risk (RR) 0.75], as well as incidence of 1year graft loss by $25 \%$ [13]. Two pediatric randomized controlled trials (RCTs) proved that adding anti-CD25 Ab basiliximab to triple-maintenance protocol tacrolimus/ azathioprine/prednisolone (TAC/AZA/Pred) or cyclosporin $\mathrm{A} / \mathrm{MMF} /$ Pred (CsA/MMF/Pred) in patients of low to moderate immunological risk is not justified, as the incidence of rejection and patient and graft survival was no different in children with or without induction $[14,15]$. Monoclonal induction was also used in a majority of pediatric clinical trials on steroid minimization. The Stanford complete steroid avoidance study was based on an extended daclizumab induction (overall nine doses) [12]. Only two daclizumab doses of $1 \mathrm{mg} / \mathrm{kg}$ were used in the TWIST trial, and steroids were stopped at day 5 after surgery [16]. It should be noted that daclizumab is no longer manufactured, and two doses of basiliximab were used in further pediatric trials on steroid withdrawal [17-19]. Early and long-term results of all these and other trials have shown that in pediatric patients with low to moderate immunological risk, monoclonal induction with anti-CD25 Ab with combination TAC/MMF therapy was sufficient to allow early steroid withdrawal, resulting in all expected clinical benefits, including better growth, with no detrimental effect on long-term patient/graft survival and renal function [20]. Basiliximab was also used in the innovative protocol, which aimed to double the minimization of immunosuppression (CNI plus steroids). With monoclonal induction and use of everolimus, reduced exposure to cyclosporine was possible; in further follow-up, with a normal renal biopsy, the late ( $>6$ months after transplantation) steroid withdrawal was also possible. This protocol was very effective in patients at low immunological risk, with no rejection within 1 year and with $100 \%$ patient and graft survival in the 3-year follow-up [21]. The ongoing multicenter CRADLE RCT aims at verifying the efficacy and safety of a similar protocol but with Csa replaced by TAC, especially in the subgroup of patients given basiliximab, as monoclonal induction with basiliximab is not mandatory in this trial and depends on the individual decisions of each center (www.clinicaltrials.gov/ct2/show/ NCT01544491).

Induction with basiliximab and the then new drug belatacept, administered IV every 2 weeks then repeated 
Table 2 Biologic agents used in pediatric renal transplantation in clinical practice: indications, duration of effect, and monitoring

\begin{tabular}{|c|c|c|c|c|c|}
\hline Drug & Group & Indications & $\begin{array}{l}\text { Duration of effect } \\
\text { on target cells }\end{array}$ & Monitoring & $\begin{array}{l}\text { Number } \\
\text { of doses }\end{array}$ \\
\hline Basiliximab & $\mathrm{MAb}$ & induction & $\begin{array}{l}\text { up to } 56 \text { days } \\
\text { (with } 2 \text { doses) }\end{array}$ & $\begin{array}{l}\text { Receptor CD20 saturation } \\
\text { or drug concentration in } \\
\text { serum (possible; not } \\
\text { routinely used) }\end{array}$ & 2 \\
\hline Daclizumab* & MAb & induction & $\begin{array}{l}\text { number of doses, } \\
\text { dependent effect }\end{array}$ & $\begin{array}{l}\text { receptor CD20 saturation } \\
\text { or drug concentration in } \\
\text { serum (not routinely used) }\end{array}$ & $2-6$ \\
\hline Alemtuzumab*** & $\mathrm{MAb}$ & $\begin{array}{l}\text { Induction; treatment } \\
\text { of rejection } \\
\text { (not routine) }\end{array}$ & up to 12 months & CD52 count & $1-2$ \\
\hline Rituximab*** & $\mathrm{MAb}$ & $\begin{array}{l}\text { desensitization; } \\
\text { refractory } \\
\text { recurrence } \\
\text { of nephrotic } \\
\text { syndrome }\end{array}$ & $\begin{array}{l}\text { up to } 12 \text { months } \\
\text { (cumulative dose- } \\
\text { dependent effect) }\end{array}$ & CD19 count & $1-4$ \\
\hline Eculizumab*** & $\mathrm{MAb}$ & $\begin{array}{l}\text { recurrence of } \\
\text { aHUS; prophylaxis } \\
\text { or treatment humoral } \\
\text { rejection*** }\end{array}$ & $\begin{array}{l}14 \text { days } \\
\text { (after single dose) }\end{array}$ & $\begin{array}{l}\text { C5-dependent functional } \\
\text { assay, TCC, CH50 } \\
\text { in serum }\end{array}$ & $1-* *$ \\
\hline $\begin{array}{l}\text { Anti-T-cell Ab } \\
\text { (thymoglobulin; ATG) }\end{array}$ & polyclonal ab & $\begin{array}{l}\text { induction; steroid-resistant } \\
\text { rejection }\end{array}$ & $\begin{array}{l}\text { Up to } 12 \text { months } \\
\text { (cumulative } \\
\text { dose-dependent effect) }\end{array}$ & $\begin{array}{l}\text { CD3 count } \\
\text { WBC count }\end{array}$ & $1-10$ \\
\hline IVIG & Immunoglobulin & Desensitization & $* * * *$ & no & $2-6$ \\
\hline
\end{tabular}

$A T G$ antithymocyte globulin, $A b$ antibodies, $M A b$ monoclonal antibodies, $a H U S$ atypical hemolytic uremic syndrome, IVIG intravenous immunoglobulin G, TTC terminal complement complex, CH50 $50 \%$ hemolytic complement activity, WBC white blood cell

*not available since 2009

**undefined number of doses in prophylaxis of genetic HUS recurrence after renal transplantation

*** off-label in transplantation

**** duration of IVIG effect on circulating Ab is difficult to evaluate, as their further production is blocked by rituximab given simultaneously (in nonplasmapheresis protocols); significant decrease in anti-HLA Ab class II titer as early as from days 10-20 after first dose of IVIG was reported [35]

infusions every 4 weeks, was used for prophylaxis of acute rejection in adult patients after renal transplantation, randomized to three arms, including two with different dosages of belatacept and one with CsA, all combined with MMF and steroids. At 1 year, both belatacept arms showed no inferiority to the CsA arm in terms of graft and patient survival, with better renal function in belatacept arms. An important clinical benefit was better metabolic profile in belatacept-treated patients; however, there was a safety concern related to high posttransplant lymphoproliferative disease (PTLD) rate in Epstein-Barr virus (EBV)-seronegative patients [5]. Another option of monoclonal antibody induction was the use of alemtuzumab, primarily in children, by Pittsburgh group, who used the single dose of $0.4-0.5 \mathrm{mg} / \mathrm{kg}$, followed by TAC monotherapy and early steroid withdrawal (at 1-5 days after transplantation). Using this approach and long-lasting depletion of target cells, maintenance immunosuppression was limited to TAC monotherapy [22, 23].

An innovative protocol of alemtuzumab induction $(30 \mathrm{mg} /$ dose) with monthly belatacept IV (10 mg/ $\mathrm{kg} / \mathrm{dose})$ and daily sirolimus given after renal transplantation to avoid calcineurin and steroid exposure in 20 adult renal transplant recipients was recently reported. There was no acute rejection or de novo donor-specific antibody (DSA) production within the first year. Ten patients remained on belatacept as the single immunosuppressive drug [24].

\section{Polyclonal induction}

In a retrospective single-center study, 198 children and adolescents were given polyclonal combined with triplemaintenance regimen. Significantly fewer episodes of acute rejection were seen in patients treated with thymoglobulin (33\% vs $50 \%, p=0.02)$ [25]. Overall, 37 adolescents (mean age $15.2 \pm 2.8$ years) were treated with the induction protocol, including five to seven fixed doses of $1.5 \mathrm{mg} / \mathrm{kg}$ thymoglobulin combined with TAC/ MMF/Pred; there was an $8.1 \%$ incidence of acute rejection within 1 year and $91.9 \%$ graft and $100 \%$ patient survival [26]. Six fixed doses of $1.5 \mathrm{mg} / \mathrm{kg}$ thymoglobulin induction were used by the Stanford group in an early steroid withdrawal protocol in 13 children with high immunological risk, with no further rejection episode within 
Table 3 New investigational agents (not used in pediatric clinical practice or evaluated in pediatric clinical trials)

\begin{tabular}{|c|c|c|}
\hline Agent & Target & Suggested mechanism of action \\
\hline Belatacept & CD80 (B7-1), CD86 (B7-2) on APCs & $\begin{array}{l}\text { Blockade of pathway preventing production of IL-2 and conversion } \\
\text { of naïve T cells into effector T cells }\end{array}$ \\
\hline Alefacept* & $\mathrm{CD} 2$ on $\mathrm{T}$ cells & Co-stimulation inhibitor. Preferential depletion of effector T cells \\
\hline Natalizumab & VLA-4 on lymphocytes & $\begin{array}{l}\text { Blockade of interaction between VLA-4 and VCAM-1 and impairment } \\
\text { of lymphocyte trafficking into tissues }\end{array}$ \\
\hline Efalizumab* & LFA-1 (CD11a) on leukocytes & $\begin{array}{l}\text { Competitive inhibition with ICAM-1 located on APCs and impairment } \\
\text { of lymphocyte adhesion and activation }\end{array}$ \\
\hline Tasocitinib (tofacitinib) & JAK3 (JANUS tyrosine kinase) & Inhibiting signaling cascade by blocking transcriptive factors Stat $5 \mathrm{a}$ i Stat $5 \mathrm{~b}$ \\
\hline Bortezomib & Proteasome & $\begin{array}{l}\text { Inhibiting degradation of cell-cycle regulatory proteins resulting in cell-cycle } \\
\text { arrest and apoptosis; inhibiting degradation of inhibitor } \mathrm{kB} \text {, therefore } \\
\text { preventing NFKB-mediated cell activation }\end{array}$ \\
\hline ASKP1240 & $\mathrm{CD} 40$ & Blockade of CD40-positive cells \\
\hline
\end{tabular}

ASKP1240 a fully human anti-CD40 monoclonal antibody, APC antigen-presenting cell,

IL-2 interleukin-2

ICAM-1 intracellular adhesion-cell-molecule-1

$L F A-1$ lymphocyte-function-associated antigen

$V C A M-1$ vascular adhesion-cell-molecule-1

$V L A-4$ very late antigen-4, $N F \kappa B$ nuclear factor kappa B

*No further investigation in transplantation

1-year follow-up, normal picture biopsies performed every 3 months up to 1 year after transplantation, and no de novo DSA [27]. Overall, five to seven doses of $1.5 \mathrm{mg} / \mathrm{kg}$ thymoglobulin were given to 21 pediatric patients undergoing an early steroid minimization protocol compared with six to 15 doses given as steroid maintenance (retrospective control group). With steroid withdrawal on day 6 , the incidence of acute rejection was $23 \%$ and graft survival $90 \%$ at 1 year, which was no different than in controls [28].

The optimal number of thymoglobulin doses (days of treatment) in induction protocols is not defined. The attempt to keep optimal balance between efficacy and safety is the basis of using short ( $<3$ doses) or longer (up to 10 doses) induction and adjusting the dose to trough $\mathrm{CD} 3$ (target 50 $100 / \mathrm{mm}^{3}$ ) or WBC count (target $>3000 / \mathrm{mm}^{3}$ ) versus a fixed dose of $1.5 \mathrm{mg} / \mathrm{kg}[29,30]$. The median cumulative dose in adult renal graft recipients in TAILOR registry data was $5 \mathrm{mg} / \mathrm{kg}$ per treatment (1.56-15.00); $46.6 \%$ of patients (overall $n=2,322$ ) received between 1.5 and $5 \mathrm{mg} / \mathrm{kg}, 35.4 \%$ from 5 to $7 \mathrm{mg} / \mathrm{kg}$, and $18 \%$ from 7 to $15 \mathrm{mg} / \mathrm{kg}$ per treatment. Up to $64.6 \%$ of patients tolerated the full intended induction dose [31]. The US Organ Procurement and Transplantation Network (OPTN) database stratified the incidence of based

Table 4 Clinical experience with novel drugs (still being investigated) in adult transplant populations

\begin{tabular}{|c|c|c|c|c|}
\hline Agent & Major reports & $\begin{array}{l}\text { Clinical indication; } \\
\text { treated populations }\end{array}$ & Efficacy; other benefits & Safety; specific caution \\
\hline Belatacept & $\begin{array}{l}\text { RCTs: BENEFIT } \\
\text { study BENEFIT } \\
\text { EXT study }\end{array}$ & $\begin{array}{l}\text { Induction: adults } \\
\qquad(n=445 ; \text { in two } \\
\text { treatment arms); } \\
\text { adults }(n=102)\end{array}$ & $\begin{array}{l}\text { Not inferior to CNI-based } \\
\text { triple regimen. Better } \\
\text { metabolic profile compared } \\
\text { to CNI }\end{array}$ & $\begin{array}{l}\text { High risk of PTLD (CNS specific); } \\
\text { strongly contraindicated in } \\
\text { EBV-naïve patients }\end{array}$ \\
\hline $\begin{array}{l}\text { Tasocitinib } \\
\text { (tofacitinib) }\end{array}$ & $\mathrm{RCT}$ & $\begin{array}{l}\text { Induction: adults }(n=40, \\
\text { in two treatment arms) }\end{array}$ & $\begin{array}{l}\text { Not inferior to CNI-based } \\
\text { triple regimen }\end{array}$ & $\begin{array}{l}\text { High rate of viral infection } \\
\text { Dyslipidemia }\end{array}$ \\
\hline ASKP1240 & RCT & $\begin{array}{l}\text { Induction: overall } 38 \\
\quad(3 \text { treatment arms) }\end{array}$ & $\begin{array}{l}\text { Not inferior to CNI-based } \\
\text { triple regimen }\end{array}$ & Significant rate of infections \\
\hline Bortezomib & Case series & $\begin{array}{l}\text { Desensitization: treatment } \\
\text { of antibody-mediated } \\
\text { rejection; largest } \\
\text { series } n=70 \text { ) }\end{array}$ & Promising & Anemia; peripheral neuropathy \\
\hline
\end{tabular}

$R C T$ randomized controlled trial $C N S$ central nervous system, $C N I$ calcineurine inhibitor, PTLD posttransplant lymphoproliferative disease, EBV Epstein-Barr virus 
Table 5 Evidence-based medicine level of clinical experience with biologics in pediatric renal transplantation

\begin{tabular}{|c|c|c|c|c|}
\hline Indication & Agents & Type of report & $\begin{array}{l}\text { Overall number } \\
\text { of treated patients* }\end{array}$ & Overall outcome \\
\hline Induction & $\begin{array}{l}\text { Anti-CD25 } \mathrm{Ab} \\
\text { anti-CD52 Ab; } \\
\text { polyclonal Ab }\end{array}$ & $\begin{array}{l}\text { International and national } \\
\text { multicenter RCTs: single- } \\
\text { center prospective trials, } \\
\text { single-center case-control } \\
\text { studies }\end{array}$ & 1,503 & $\begin{array}{l}\text { Favorable graft and patient survival; clinical } \\
\text { benefit from steroid or/and CNI minimization } \\
\text { (in relevant studies); satisfactory safety profile }\end{array}$ \\
\hline $\begin{array}{l}\text { Desensitization; HLA } \\
\text { incompatible ABO } \\
\text { incompatible }\end{array}$ & IVIG, rituximab & Case series and case reports & 65 & $\begin{array}{l}\text { Transplantation possible; shorter waiting time; } \\
\text { no proven long-term efficacy. Transplantation } \\
\text { possible; favorable long-term patient and graft } \\
\text { survival }\end{array}$ \\
\hline $\begin{array}{l}\text { Treatment of primary } \\
\text { disease recurrence }\end{array}$ & $\begin{array}{l}\text { Rituximab, } \\
\text { eculizumab }\end{array}$ & Case series and case reports & 38 & $\begin{array}{l}\text { Variable efficacy in NS. Effective prophylaxis in } \\
\text { most cases of aHUS. Effective in treatment of } \\
\text { aHUS recurrence }\end{array}$ \\
\hline $\begin{array}{l}\text { Treatment of steroid } \\
\text { resistant rejection }\end{array}$ & $\begin{array}{l}\text { Polyclonal } \mathrm{Ab}: \\
\text { rituximab, } \\
\text { alemtuzumab }\end{array}$ & $\begin{array}{l}\text { Single-center prospective trials; } \\
\text { case series and case reports }\end{array}$ & 27 & Variable efficacy in acute rejection \\
\hline $\begin{array}{l}\text { Treatment of chronic } \\
\text { humoral rejection }\end{array}$ & IVIG, rituximab & $\begin{array}{l}\text { Single-center prospective trials; } \\
\text { case series and case reports }\end{array}$ & 26 & Effective in majority $(70 \%)$ of reported patients \\
\hline
\end{tabular}

$H L A$ human leukocyte antigen, $\mathrm{AB}$ antibodies, $I V I G$ intravenous immunoglobulin, $R C T$ randomized controlled trials, $C N I$ calcinurine inhibitors, $N S$ nephrotic syndrome, aHUS atypical hemolytic uremic syndrome

* Overall number of patients means the sum of cases presented in quoted publications listed in the text, not the overall number of patients ever treated with a particular drug

on depleting and nondepleting agents: lymphocyte-depleting $\mathrm{Ab}$ were used in $47.5 \%$ and IL-2R antibodies in $43 \%$ of 1,276 children treated with steroid minimization protocols and induction between 2002 and 2009 [32].

Summarizing: induction with biologic agents, such as antiIL2 Ab (basiliximab) or polyclonal $\mathrm{Ab}$, after verification in clinical trials and reports, has entered routine practice in selected patients with clear clinical indications.

\section{Biologics in desensitization of HLA-incompatible renal-graft recipients}

In patients awaiting renal transplantation, reducing the titer of pre-formed anti-HLA antibodies by using plasmapheresis (PF), IVIG administration alone, combined with PF, or rituximab was reported in several adult studies and a few pediatric case reports [33-35]. The most common protocol used in adult patients in the USA was based on a combination of IVIG and PF ( $82 \%$ ), and preoperative rituximab was used in more than half of reporting centers [36]. The combination of IVIG and rituximab was used by Jordan's group to reduce the titer of pre-formed anti-HLA antibodies in highly sensitized patients awaiting renal transplantation [37]. The authors described the protocol based on administration of $2 \mathrm{~g} / \mathrm{kg}$ IVIG on the days 0 and 30 , combined with rituximab $\left(375 \mathrm{mg} / \mathrm{m}^{2}\right)$ given on days 7 and 22 (after first dose if IVIG). This protocol caused significant reduction of mean panel-reactive antibody (PRA) level from $77 \pm 19 \%$ to $44 \pm 30 \%(p<0.0001)$ after second infusion of IVIG and shortened the waiting time to successful transplantation from $144 \pm 89$ months to $5 \pm$ 6 months. Regardless of the encouraging short-term results, the long-term efficacy of the desensitization protocol was questioned in adult patients in a retrospective comparative cohort study. The 1- and 5-year graft survival rate was significantly inferior in patients who underwent the desensitization protocol based on a course of PF combined with IVIG and then depletional induction (89.9 vs $97.6 \%$ and 69.4 vs $80.6 \%$, respectively). The overall risk of graft loss was significantly higher in desensitized patients [hazard ratio (HR) 2.6; $p=0.04$ )] but with no detrimental effect on patient survival [38].

\section{Biologics in ABO-incompatible renal transplantation}

Other specific desensitization protocol was used by Tyden et al. in living- donor ABO-incompatible pediatric transplantation. The pretransplant protocol included a single dose of $375 \mathrm{mg} / \mathrm{m}^{2}$ rituximab given 4 weeks before scheduled immunoadsorption, triple immunosuppression, four sessions of antigen-specific immunoadsorption, followed by $0.5 \mathrm{~g} / \mathrm{kg}$ IVIG preoperatively and continuation of immunoadsorption after surgery. Five-year patients survival rate was $98 \%$ and graft survival rate $97 \%$ [39], which are obviously not inferior to outcomes in ABO-compatible transplantation. Eculizumab was used to enhance the desensitization protocol (PF followed by polyclonal induction) in adult patients undergoing living- 
donor renal transplantation against positive cross match in terms of preventing antibody-mediated rejection (AMR). Overall, 26 patients received preemptively $1,200 \mathrm{mg}$ of eculizumab immediately before transplantation, then $600 \mathrm{mg}$ on day 1 , then four times weekly. Further dosing was adjusted to the presence of DSA. The incidence of antibody-mediated rejection (AMR) was $7.7 \%$ vs $41.2 \%$ in the control group $(p=0.0031)$ [40]. Bortezomib (4 x $\left.1.3 \mathrm{~g} / \mathrm{m}^{2}\right)$ was given preemptively (early posttransplant) to remove de novo DSA (before expected further humoral rejection occurs). In a series of 26 patients, bortezomib combined with steroids was given within a mean of 30 days after DSA appearance $(n=26)$, with PF and rituximab $(n=9)$, with PF only $(n=5)$, or with IVIG $(n=1)$. There was significant reduction in DSA level at 1 year $(p=0.002)$, correlated with better allograft function at a mean of 25.8 months of follow-up [41].

Summarizing: Desensitization of HLA-incompatible patients with biologic agents (or combination of biologics with plasma exchange) allows further renal transplantation and may shorten the waiting time for transplant. However, these patients still present a high risk of rejection and inferior long-term graft survival. This will be very important in pediatric renal-graft recipients, who have a long life expectancy on renal replacement therapy. A specific desensitization protocol, as described by Tyden et al., allows successful ABO-incompatible renal transplantation with excellent long-term outcome.

\section{Biologics in recurrence of primary disease after renal transplantation}

Eculizumab has been used in prophylaxis and treatment of posttransplant recurrence of aHUS. The report by the French Group for Atypical HUS assessed 22 pediatric cases in their retrospective multicenter study. Thirteen patients were treated due to recurrence, and nine received pre-emptive eculizumab as prophylaxis. Single and multiple doses were given is cases presenting several $\mathrm{CFH}$, $C F I$, and $C 3$ gene mutations. Some patients were resistant to PF $(n=10)$, and some were PF dependent $(n=2)$. In some cases, the picture of renal biopsy included signs of acute rejection. All but one patient from the prophylaxis group remained recurrence free at a mean 14.5-month follow-up. In all 13 patients with recurrence, the hematological features of aHUS rapidly returned to normal following eculizumab administration, whereas mean creatinine concentration dropped from a mean of $295 \pm 171$ to $135 \pm 69 \mu \mathrm{mol} / \mathrm{L}(p=0.002)$ within 3 subsequent months. Patients with delayed introduction of eculizumab treatment (>28 days after diagnosis) had lower functional benefit than patients treated earlier after aHUS onset [42]. Rituximab was used to treat recurrence of severe
NS in a series of children after renal transplantation. One to four doses (of $375 \mathrm{mg} / \mathrm{m}^{2}$ ) were given, and complete or partial response was observed in six of seven patients [43]. Variable response to one to four doses of rituximab was reported in series of eight patients; complete response was seen in two and partial in four. In some cases, there was a correlation between CD19 depletion and clinical response and between CD19 recovery and relapses; in others, there was no association between CD19 count and clinical course of NS [44]. The efficacy of rituximab (four doses) in a girl with Finnish-type congenital NS and clinical "recurrence" due to anti-nephrin Ab production was reported. Remission was sustained during the 5-year follow-up [45].

Summarizing: recurrence of severe primary renal diseases has become potentially treatable with currently available biologic agents (rituximab and eculizumab); however, important limitations remain, including overall efficacy and safety for rituximab and enormous financial cost for eculizumab in prolonged prophylaxis.

\section{Biologics in rejection therapy}

\section{Acute rejection}

Acute rejection is associated with allograft infiltration by several cell types, including $\mathrm{T}$ and $\mathrm{B}$ cells, macrophages, and NK cells. Polyclonal Ab therapy is commonly used in steroid-resistant cases. The significant presence of B cells in biopsy-proven infiltrate may suggest that rituximab might be useful. The Stanford group conducted a randomized trial comparing 4 weekly doses of rituximab $\left(375 \mathrm{mg} / \mathrm{m}^{2}\right)$ versus thymoglobulin $(6 \times 1.5 \mathrm{mg} / \mathrm{kg})$ in 20 pediatric renal recipients with late acute rejection (mean time from transplantation to rejection 34 and 21.36 months) in two arms of ten patients each. All patients were pretreated with methylprednisolone (MP). . In six patients in the rituximab group and two from the control group, humoral component of rejection was confirmed by CD4 presence. The presence of CD20 cells in graft infiltrates was confirmed in all patients. Results confirmed the efficacy of rituximab therapy in CD20positive acute rejection [46]. Limited efficacy of singledose $(0.3 \mathrm{mg} / \mathrm{kg})$ alemtuzumab in rescue treatment of late acute cellular rejection was reported in three children at high immunological risk, with recurrent episodes of rejection and poor previous response to other therapies (including steroids and polyclonal Ab) [47]. More successful treatment was described in 15 adult patients. The use of multiple doses (4-10 days, dose 6-10 mg/kg) showed no increase in malignancy or cytomegalovirus (CMV) infection over 10 years of follow-up despite, high doses used 
in this study [48]. Whether or not this difference in efficacy was related to the use of single versus multiple doses, rejection type, or patient specificity is not clear. Three successful pediatric cases of ABR were reported with the use of MP, $2 \mathrm{~g} / \mathrm{kg}$ IVIG, a single dose of rituximab $\left(375 \mathrm{mg} / \mathrm{m}^{2}\right)$, and course of plasma exchange (up to ten procedures) [49]. The protocol proposed by Jordan et al., based on clinical experience, distinguished patients with less and more pronounced pathologic features of ABR. Those with a milder clinical picture received a combination of three MP pulses, initial dose of $2 \mathrm{~g} / \mathrm{kg}$ IVIG given between first and second pulses, and a single dose of rituximab $\left(375 \mathrm{mg} / \mathrm{m}^{2}\right)$ on day 2 , followed by two consecutive MP pulses. The second (and last) dose of $2 \mathrm{~g} / \mathrm{kg}$ IVIG was given between 30 and 60 days of treatment. More severe cases, with signs of thrombotic microangiopathy in biopsy, were treated with a series of $\mathrm{PF}$, followed by single doses of IVIG $(2 \mathrm{~g} / \mathrm{kg})$ and a single dose of rituximab $\left(375 \mathrm{mg} / \mathrm{m}^{2}\right)$ [50]. Bortezomib, in a retrospective comparison with rituximab, was reported in ten adult patients treated also with MP, PF (six sessions), and IVIG (30 g/treatment) [51]. The efficacy of bortezomib was lower in cases of late AMR, i.e., occurring $>6$ months after transplantation. Delay in diagnosis and difference in characteristics of cells producing DSA in late-onset AMR (long-lived plasma-cell population) is proposed as an explanation of a worse response [52]. Eculizumab was successfully used in a hyperimmunized 17-year-old patient with PF resistant of acute humoral rejection, developing in the second graft, after a desensitization protocol based on combined PF, IVIG, and rituximab. The patient was treated with MP, repeated PF, and IVIG; however, DSA and ongoing rejection persisted, proven in repeated biopsy, despite 45 sessions of PF and absence of CD19 cells. Four doses of eculizumab $(600 \mathrm{mg})$ were given, and remission was present at the third biopsy. Eculizumab was then continued on a monthly basis (eight doses) due to increasing DSA titer, which appeared after PF was stopped. Two years after therapy, the patient was stable, with creatinine concentration of $1.2 \mathrm{mg} / \mathrm{dl}$ and DQ DSA of mean fluorescent intensity (MFI) 5,000 [53]. Similar reports were published regarding eculizumab efficacy in highly sensitized adults patients developing acute humoral rejection despite pretransplant (PF/IVIG/rituximab) desensitization and use of polyclonal induction; one to five doses of eculizumab were used in rescue therapy $[54,55]$.

Chronic humoral rejection

The protocol described by Jordan et al. in patients with chronic antibody-mediated rejection as a result of the presence of de novo DSA had three options: IVIG alone, IVIG plus rituximab, and combination of plasmapheresis with lower dose of IVIG $(1 \mathrm{~g} / \mathrm{kg})$ with or without rituximab [50]. The combination of IVIG $(4 \times 1 \mathrm{~g} / \mathrm{kg})$ and a single dose of rituximab $\left(375 \mathrm{mg} / \mathrm{m}^{2}\right)$ given 1 week after last IVIG dose was reported as a therapeutic tool for chronic humoral rejection in six children: four responded to antirejection therapy and showed increased glomerular filtration rate (GFR) within 12 months: significantly at 6 months by $21 \mathrm{ml} / \mathrm{min} / 1.73 \mathrm{~m}^{2}(p<0.05)$ and then not significantly at 12 months by $19 \mathrm{ml} / \mathrm{min} / 1.73 \mathrm{~m}^{2}(p=$ 0.063 ) [56]. The same protocol (four doses of IVIG $1 \mathrm{~g} / \mathrm{kg}$ plus a single dose of $375 \mathrm{mg} / \mathrm{m}^{2}$ rituximab) was used in a prospective study recruiting 20 children with Banff diagnostic criteria of Ab-mediated rejection together with CD20-positive infiltrates (12 (60\%) patients). The response rate was $70 \%$ (14 patients) [57]. Bortezomib $(4 \times 1.3 \mathrm{~g} / \mathrm{m} 2)$ was used in adult patients with humoral rejection as a single rescue agent or in combination with IVIG or PF [58].

Summarizing: Availability of biologic agents increases the range of therapeutic tools in resistant, acute, and humoral chronic allograft rejection. However, selecting the potentially most effective treatment protocol requires very detailed diagnosis based on close DSA monitoring and interpretation of results and relevant pathomorphologic evaluation, including the phenotype of infiltrating cells ( $T$ or B). There remains a need for further clinical investigation in this area.

\section{Safety concerns with biologic agents in clinical practice}

Biologic agents used in renal transplantation are highly potent immunosuppressants, interfering with normal immune response and therefore increasing the risk of specific complications. Their safety profile is variable and might be dose dependent and related to cumulative side effects of certain drugs combinations. The safety profile of commonly used biologics is summarized in Table 6 [59-66].

Posttransplant lymphoproliferative disease

The risk of posttransplant lymphoproliferative disease (PTLD) in pediatric renal graft recipients is higher than in adults mainly due to higher incidence of EBV seronegativity in the first decade of life, and depletional induction is regarded as an additional risk factor. The incidence of PTLD was significantly higher in children < 10 years of age treated with polyclonal $\mathrm{Ab}[59,60]$. Analysis of PTLD risk relation used various antibodies in 59,560 kidney recipients [data from the Organ Procurement and Transplantation Network/United Network for Organ Sharing (OPTN/UNOS)], including 
Table 6 Safety profile of biologics used in pediatric renal transplantation

\begin{tabular}{|c|c|c|c|c|c|c|}
\hline Event & $\begin{array}{l}\text { Anti-IL-2R } \\
\text { (basiliximab, } \\
\text { daclizumab) }\end{array}$ & $\begin{array}{l}\text { Polyclonal } \\
\mathrm{Ab} \text { (ATG) }\end{array}$ & Alemtuzumab & Rituximab & Eculizumab & IVIG \\
\hline $\begin{array}{l}\text { Cytokine release syndrome } \\
\text { (fever, chills, hypotension) }\end{array}$ & $0 /+$ & +++ & + & $0 /+$ & 0 & 0 \\
\hline Hypersensitivity reactions & ++ & +++ & + & + & + & + \\
\hline Bone marrow complications & + & +++ & + & + & + & 0 \\
\hline Lymphopenia & + & +++ & +++ & +++ & 0 & 0 \\
\hline Malignances & 0 & ++ & + & 0 & 0 & 0 \\
\hline Viral infections (CMV, EBV, BKV, other) & + & +++ & ++ & + & ++ & + \\
\hline Bacterial and fungal infections & + & ++ & ++ & $0 /+$ & $0 /+$ & + \\
\hline Specific antibody formation & + & ++ & 0 & 0 & 0 & 0 \\
\hline Other (specific) & & & & RALI & $\begin{array}{l}\text { Higher risk of } \\
\text { meningitis } \\
\text { (vaccination } \\
\text { mandatory) }\end{array}$ & $\begin{array}{l}\text { Transient } \\
\text { acute kidney } \\
\text { injury }\end{array}$ \\
\hline
\end{tabular}

$C M V$ cytomegalovirus, $E B V$ Epstein-Barr virus, $B K V$ BK virus, $I L-2$ interleukin 2, $A b$ antibodies $A T G$ antithymoglobulin, $R A L I$ rituximab-associated lung injury, $I V I G$ intravenous immunoglobulin,

3,105 children, showed that only polyclonal induction was associated with significant risk (RR 1.63, $p=0.0025$ vs no induction). Additional factors included age $<18$ years (RR 3.67; $p<0.0001$ ), seronegative EBV (RR 5.225; $p<0.0001$ ), CMV (RR 2.036; $p<0.0001$ ) status, and-interestingly - the use of sirolimus in maintenance immunosuppression (RR 2.047; $p<0.0001$ ) [61]. A more recent report provides data on a higher risk of PTLD in patients receiving alemtuzumab for induction [62]. Pretransplant EBV seronegative status was also a risk factor of PTLD in children given nondepletional induction with basiliximab combined with sirolimus, tacrolimus, or cyclosporine, and steroids. Up to $6.9 \%$ of patients developed PTLD. This was mainly seen in young EBV-naïve children receiving an EBV-seropositive renal allograft [18]. Of note is the specific relation of the new drug belatacept to PTLD (in adult patients): in EBVseronegative cases, treatment was associated with a high incidence of PTLD, affecting in particular the central nervous system [5]. As the incidence of EBV-seronegative status is much higher in the first decade of life [59], the safety of further use of belatacept in pediatric patients is questionable.

\section{Infections}

As reported by North American Pediatric Renal Trials and Collaborative Studies (NAPRTCS), induction is associated with significant higher risk of infection [odds ratio (OR) $1.45 ; p<0.001$ ), especially in terms of viral etiology (OR $1.47 ; p=0.003$ ) and in young children $<2$ years of age, including the risk of $\mathrm{BK}-\mathrm{JC}$ polyoma-virus (JVC)-related nephritis. The incidence of hospitalization within 2 years of follow-up (after induction) due to viral infections was about $30 \%$ and bacterial infections about $28.4 \%[63,64]$. Specific vaccination is mandatory with the use of eculizumab to prevent meningitis [42]. The association between treatment with rituximab JVC and, in consequence, development of progressive multifocal leukoencephalopathy (PML) was reported mainly in bone marrow transplant patients. The relevant report described $5.5 \%$ incidence of JVC replication in adult solid-organ recipients (in the majority renal transplant patients) treated with rituximab, suggesting the need for close monitoring [65].

Rituximab-specific serious adverse event: rituximab-associated lung injury

Rituximab-associated lung injury was reported in patients treated with anti-CD20 Ab. This life-threatening syndrome may include interstitial pneumonitis, alveolar-interstitial pneumonia, and rapidly progressing pulmonary fibrosis. The need for mechanical ventilation is a predictor of poor prognosis [66].

Summarizing: Use of biologic agents is associated with risk of several general or drug-specific adverse events; therefore, the risk/potential clinical benefit ratio must be carefully balanced. EBV-seronegative status, the most common in children $<10$ years of age, is a specific problem in the pediatric population and may limit or increase the risk of biologic agent use.

Key points regarding the use of biologics in rejection therapy are:

- Biologics are used in transplantation to remove circulating antibodies and block their production, to reduce further exposure to toxic maintenance immunosuppressives, to treat recurrence of specific primary disease, and to treat severe rejection. 
- Depending on indication, biologics may be used before and early and late after renal transplantation.

- Clinically additive mechanisms of action promote a combination of these drugs in specific clinical situations, such as desensitization or humoral rejection.

- Biologic targeting of receptors on different cells may enhance the risk of serious adverse events, despite specific prophylactic measures.

\section{Research points in biologics use in rejection therapy are:}

- Optimal treatment protocol for chronic humoral rejection should be established in controlled trials.

- Optimal combinations of biologic agents (and/or extracorporeal procedures) aimed to reduce circulating DSA level for prophylaxis of humoral rejection need to be established in sensitized candidates for transplantation and active post-transplant de novo DSA producers Optimal treatment of primary disease recurrence after transplantation, including rituximab for NS and eculizumab for aHUS, should be verified in controlled trials.

\section{Conflict of interests None.}

\section{Questions (answers are provided following the reference list)}

1. Monoclonal antibodies $(\mathrm{Ab})$ used in renal transplantation:

a. Are always depleting $\mathrm{Ab}$

b. Are aimed to B cells only

c. May be depleting or blocking $\mathrm{Ab}$

d. Are used only to treat rejection

e. Are not used in children

2. The effect of biologics on specific cell-target receptors:

a. Is always longer with the use of polyclonal $\mathrm{Ab}$

b. Is never longer than 2 weeks after a single dose

c. Is shorter in tacrolimus-treated patients

d. Is drug and dose dependent and may last from 2 weeks to $>12$ months

e. Has no clinical importance, as this depends on maintenance immunosuppression

3. The risk of PTLD is higher in young children receiving biologic agents after renal transplantation because:

a. They are more frequently desensitized than adolescents

b. They have higher risk of recurrence of primary disease

c. They need more blood transfusions after transplantation

d. They are more often EBV-seronegative $<10$ years of age

e. They often have tonsillitis

4. Combination of IVIG and rituximab, used for desensitization or treatment of humoral rejection:

a. Is given to block T-cell-derived cytokines

b. Allows removal of circulating DSA and blocks their further production by B cells

c. Decreases the risk of rituximab-related infectious complications by IVIG

d. Is not used in children

e. Is used in minimization protocols

5. While administering depletional antibodies:

a. There is no need for monitoring

b. Monitoring drug concentration is mandatory c. Monitoring target-cell count is useful to assess the effect and sometimes adjust the next dose

d. Monitoring concomitant CNI concentration is necessary, as there is CYP3P-driven interaction

e. Every dose must be adjusted to current $\mathrm{CD} 4 / \mathrm{CD} 8$ ratio

Open Access This article is distributed under the terms of the Creative Commons Attribution License which permits any use, distribution, and reproduction in any medium, provided the original author(s) and the source are credited.

\section{References}

1. Halloran PF (2004) Immunosuppressive drugs for kidney transplantation. N Eng J Med 351:2715-2729

2. Shehata N, Palda V, Meyer RM, Blydt-Hansen TD, Campbell P, Cardella C, Martin S, Nickerson P, Peltekian K, Ross H, Waddell TK, West L, Anderson D, Freedman J, Hume H (2010) The use of immunoglobulin therapy for patients undergoing solid organ transplantation: an evidence-based practice guideline. Transfusion Med Rev 24(1):S7-S27

3. De Serres SA, Yeung M, Mfarrej B (2011) Najafian N (2011) Effect of biologic agents on regulatory T cells. Transplant Rev 25:110-116

4. Hardinger K, Brennan D (2013) Novel immunosuppressive drugs in kidney transplantation. World J Transplant 3(4):68-77

5. Vincenti F, Charpentier B, Vanrenterghem Y, Rostaing L, Bresnahan B, Darji P, Massari P, Mondragon-Ramirez GA, Agarwal M, Di Russo G, Lin CS, Garg P, Larsen CP (2010) A phase III study of Belatacept-based immunosuppression regimens versus cyclosporine in renal transplant recipients (BENEFIT Study). Am J Transplant 10: $535-546$

6. Vincenti F, Blancho G, Durrbach A, Friend P, Grinyo J, Halloran PF, Klempnauer J, Lang P, Larsen CP, Mühlbacher F, Nashan B, Soulillou JP, Vanrenterghem Y, Wekerle T, Agarwal M, Gujrathi S, Shen J, Shi R, Townsend R, Charpentier B (2010) Five-Year Safety and Efficacy of Belatacept in Renal Transplantation. J Am Soc Nephrol 21:1587-1596

7. Busque S, Leventhal J, Brennan D, Steinberg S, Klintmalm G, Shah T, Mulgaonkar S, Bromberg JS, Vincenti F, Hariharan S, Slakey D, Peddi VR, Fisher RA, Lawendy N, Wang C, Chan G (2009) Calcineurin-inhibitor-free immunosuppression based on the JAK inhibitor CP-690,550: a pilot study in de-novo kidney allograft recipients. Am J Transplant 9:1936-1945

8. Vincenti F, Yang H, Klintmalm G, Steinberg S, Wang L, Zhang W, Conkle A, Blahunka P, First R, Holman J (2013) Clinical outcomes in phase $1 \mathrm{~b}$, randomized double-blind, parallel, placebo-controlled, single-dose study of ASKP1240 in de novo kidney transplantation. Am J Transplant 13: S5, abstr 181

9. Trivedi H, Terasaki P, Feroz A, Everly MJ, Vanikar AV, Shankar V, Trivedi VB, Kaneku H, Idica AK, Modi PR, Khemchandani SI, Dave SD (2009) Abrogation of anti-HLA antibodies via proteasome inhibition. Transplantation 87:1555-1556

10. Walsh R, Everly J, Brailey P, Rike AH, Arend LJ, Mogilishetty G, Govil A, Roy-Chaudhury P, Alloway RR, Woodle ES (2010) Proteasome-inhibitor based primary therapy for antibody-mediated renal allograft rejection. Transplantation 89:277-284

11. Höcker B, Kovarik J, Daniel V, Opelz G, Fehrenbach H, Holder M, Hoppe B, Hoyer P, Jungraithmayr TC, Köpf-Shakib S, Laube GF, Müller-Wiefel DE, Offner G, Plank C, Schröder M, Weber LT, Zimmerhackl LB, Tönshoff B (2008) Pharmacokinetics and immunodynamics of basiilximab in pediatric renal transplant recipients on mycophenolate mofetil comedication. Transplantation 86: $1234-1240$ 
12. Sarwal MM, Vidhun JR, Alexander SR, Satterwhite T, Millan M, Salvatierra O Jr (2003) Continued superior outcomes with modification and lengthened follow-up of a steroid-avoidance pilot with extended daclizumab induction in pediatric renal transplantation. Transplantation 76(9):1331-1339

13. Webster AC1, Ruster LP, McGee R, Matheson SL, Higgins GY, Willis NS, Chapman JR, Craig JC (2010) Interleukin 2 receptor antagonists for kidney transplant recipients. Cochrane Database Syst Rev 1:CD003897

14. Grenda R, Watson A, Vondrak K, Webb NJ, Beattie J, Fitzpatrick M, Saleem MA, Trompeter R, Milford DV, Moghal NE, Hughes D, Perner F, Friman S, Van Damme-Lombaerts R, Janssen F (2006) A prospective, randomized, multicenter trial of tacrolimus-based therapy with or without basiliximab in pediatric renal transplantation. Am J Transplant 6:1666-1672

15. Offner G, Tönshoff B, Hoecker B, Krauss M, Bulla M, Cochat P, Fehrenbach H, Fischer W, Foulard M, Hoppe B, Hoyer PF, Jungraithmayr TC, Klaus G, Latta K, Leichter H, Mihatsch MJ, Misselwitz J, Montoya C, Müller-Wiefel DE, Neuhaus TJ, Pape L, Querfeld U, Plank C, Schwarke D, Wygoda S, Zimmerhackl LB (2008) Efficacy and safety of basiliximab in pediatric renal transplant patients receiving cyclosporine, mycophenolate mofetil, and steroids. Transplantation 86(9):1241-1248

16. Grenda R, Watson A, Trompeter R, Tönshoff B, Jaray J, Fitzpatrick M, Murer L, Vondrak K, Maxwell H, van Damme-Lombaerts R, Loirat C, Mor E, Cochat P, Milford DV, Brown M, Webb NJ (2010) A Randomized Trial to Assess the Impact of Early Steroid Withdrawal on Growth in Pediatric Renal Transplantation: The TWIST Study. Am J Transplant 10:828-836

17. Delucchi A, Valenzuela M, Lillo A, Lillo AM, Guerrero JL, Cano F, Azocar M, Zambrano P, Salas P, Pinto V, Ferrario M, Rodríguez J, Cavada G (2011) Early steroid withdrawal in pediatric renal transplant: five years of follow-up. Pediatr Nephrol 26(12):2235-2244

18. Benfield MR, Bartosh S, Ikle D, Warshaw B, Bridges N, Morrison Y, Harmon W (2010) A randomized double-blind, placebo controlled trial of steroid withdrawal after pediatric renal transplantation. Am J Transplant 10:81-88

19. Montini G, Murer L, Ghio L, Pietrobon B, Ginevri F, Ferraresso M, Cardillo M, Scalamogna M, Perfumo F, Edefonti A, Zanon GF, Zacchello $G$ (2005) One-year results of basiliximab induction and tacrolimus associated with sequential steroid and MMF treatment in pediatric kidney transplant recipients. Transplant Int 18:36-42

20. Grenda R (2013) Steroid withdrawal in renal transplantation. Pediatr Nephrol 28(11):2107-2112

21. Pape L, Lehner F, Blume C, Ahlenstiel T (2011) Pediatric kidney transplantation by de novo therapy with everolimus, low-dose cyclosporine A and steroid elimination: 3-year data. Transplantation 92(6): 658-662

22. Shapiro E, Ellis D, Tan HP, Moritz ML, Basu A, Vats AN, Khan AS, Gray EA, Zeevi A, McFeaters C, James G, Jo Grosso M, Marcos A, Starzl TE (2006) Antilimphoid antibody preconditioning and tacrolimus monotherapy for pediatric kidney transplantation. J Pediatr 148(6):813-818

23. Tan HP, Donaldson J, Ellis D, Moritz ML, Basu A, Morgan C, Vats AN, Erkan E, Shapiro R (2008) Pediatric living donor kidney transplantation under alemtuzumab pretreatment and tacrolimus monotherapy: 4 years experience. Transplantation 86(12):1725-1731

24. Kirk A, Guasch A, Xu H, Cheeseman J, Mead SI, Ghali A, Mehta AK, Wu D, Gebel H, Bray R, Horan J, Kean LS, Larsen CP, Pearson TC (2014) Renal transplantation using belatacept without maintenance steroids or calcineurin inhibitors. Am J Transplant 14(5):1142-1151

25. Khositseth S, Matas A, Cook M, Bilingham K, Chavers B (2005) Thymoglobulin versus ATGAM induction therapy in pediatric kidney transplantation recipients: a single center report. Transplantation 79:958-963
26. Schwartz J, Ishitani M, Weckwerth J, Morgenstern B, Milliner D, Stegall MD (2007) Decreased incidence of acute rejection in adolescent kidney transplant recipients using antithymocyte induction and triple immunosuppression. Transplantation 84:715-717

27. Li L, Chaudhuri A, Chen A, Zhao X, Bezchinsky M, Concepcion W, Salvatierra O Jr, Sarwal MM (2010) Efficacy and safety of thymoglobulin induction as an alternative approach for steroid-free maintenance immunosuppression in pediatric renal transplantation. Transplantation 90:1516-1520

28. Chavers BM, Chang C, Gillingham KJ, Matas A (2009) Pediatric kidney transplantation using a novel protocol of rapid (6-day) discontinuation of prednisolone: 2-year results. Transplantation 88(2):237-241

29. Mourad G, Morelon E, Noël C, Glotz D, Lebranchu Y (2012) The role of Thymoglobulin induction in kidney transplantation: an update. Clin Transplant 26:E450-E464

30. Peddi VR, Bryant M, Roy-Chaudry P, Woddle ES, First MR (2002) Safety, efficacy and cost-analysis of Thymoglobuline induction therapy with intermittent dosing based on CD3+ lymphocyte counts in kidney and kidney-pancreas transplant recipients. Transplantation 73: 1514-1508

31. Gaber OA, Matas AJ, Henry ML, Brennan DC, Stevens RB, Kapur S, Ilsley JN, Kistler KD (2012) Cosimi AB: on behalf of the Thymoglobulin Antibody Immunosuppression in Living Donor Recipients Investigators (2012) Antithymocyte Globulin Induction in Living Donor Renal Transplant Recipients: Final Report of the TAILOR Registry. Transplantation 94:331-337

32. Nehus E, Goebel J, Abraham E (2012) Outcomes of steroid avoidance protocols in pediatric kidney transplant recipients. Am J Transplant 12(12):3441-3448

33. Nair V, Sawinski D, Akalin E, Friedlander R, Ebcioglu Z, Sehgal V, Dinavahi R, Khaim R, Ames S, Lerner S, Murphy B, Bromberg JS, Heeger PS (2012) Schröppel B (2012) Effect of high-dose intravenous immunoglobulin on anti-HLA antibodies in sensitized kidney transplant candidates. Clin Transplant 26(3):E261-E268

34. Valentini RP, Nehlsen-Cannarella SL, Gruber SA, Mattoo TK, West MS, Lang C, Imam AA (2007) Intravenous immunoglobulin, HLA allele typing and HLA Matchmaker facilitate successful transplantation in highly sensitized pediatric renal allograft recipients. Pediatr Transplant 11(1):77-81

35. Lobashevsky A, Higgins N, Rosner K, Mujtaba MA, Goggins WC, Taber TE (2013) Analysis of anti-HLA antibodies in sensitized kidney transplant candidates subjected to desensitization with intravenous immunoglobulin and rituximAb Transplantation 96:182-190

36. Garonzik Wang J, Montgomery R, Kucirka L, Berger JC, Warren DS, Segev DL (2011) Incompatible live-donor kidney transplantation in United States: results of national survey. Clin J Am Soc Nephrol 6: 2041-2046

37. Vo A, Lukovsky M, Toyoda M, Wang J, Reinsmoen NL, Lai CH, Peng A, Villicana R, Jordan SC (2008) Rituximab and intravenous immune globulin for desensitization during renal transplantation. N Eng J Med 359:242-251

38. Hariran A, Nogueira J, Kukuruga D, Schweitzer E, Hess J, GurkTurner C, Jacobs S, Drachenberg C, Bartlett S, Cooper M (2009) Positive cross-match living donor kidney transplantation: longerterm outcome. Am J Transplant 9:536-542

39. Tydén G, Donauer J, Wadström J, Kumlien G, Wilpert J, Nilsson T, Genberg H, Pisarski P, Tufveson G (2007) Implementation of a protocol for $\mathrm{AB} 0$-incompatible kidney transplantation-a three-center experience with 60 consecutive transplantations. Transplantation 83(9):1153-1155

40. Stegall MD, Diwan T, Raghvaiah S, Cornell LD, Burns J, Dean PG, Cosio FG, Gandhi MJ, Kremers W, Gloor JM (2011) Terminal complement inhibition decreases antibody-mediated rejection in sensitized renal transplant recipients. Am J Transplant 11:2405-2413

41. Everly M, Terasaki P, Trivedi H (2012) Durability of antibody removal following proteasome inhibitor-based therapy. Transplantation 93:572-577 
42. Zuber J, Le Quintrec M, Krid S, Bertoye C, Gueutin V, Lahoche A, Heyne N, Ardissino G, Chatelet V, Noël LH, Hourmant M, Niaudet P, Frémeaux-Bacchi V, Rondeau E, Legendre C, Loirat C, French Study Group for Atypical HUS (2012) French Study Group for Atypical HUS. Eculizumab for atypical hemolytic uremic syndrome recurrence in renal transplantation. Am J Transplant 12(12):3337-3354

43. Dello Strologo L, Guzzo I, Laurenzi C, Vivarelli M, Parodi A, Barbano G, Camilla R, Scozzola F, Amore A, Ginevri F, Murer L (2009) Use of rituximab in focal glomerulosclerosis relapses after renal transplantation. Transplantation 88(3):417-420

44. Kumar J, Shatat I, Skversky A, Woroniecki R, Del Rio M, Perelstein EM, Johnson VL, Mahesh S (2013) Rituximab in post-transplant pediatric recurrent focal segmental sclerosis. Pediatr Nephrol 28: 333-338

45. Chaudhuri A, Kambham N, Sutherland S, Grimm P, Alexander S, Concepcion W, Sarwal M, Wong C (2012) Rituximab treatment for recurrence of nephrotic syndrome in a pediatric patient after renal transplantation for congenital nephrotic syndrome of Finnish type. Pediatr Transplant 16(5):E183-187

46. Zarkhin V, Li L, Kambham N, Sigdel T, Salvatierra O, Sarwal MM (2008) A randomized prospective trial of rituximab for acute rejection in pediatric transplantation. Am J Transplant 8:2607-2617

47. Upadhyay K, Midgley L, Mougdil A (2012) Safety and efficacy of alemtuzumab in the treatment of late acute renal allograft rejection. Pediatr Transplant 16:286-293

48. Clatworthy M, Friend P, Calne R, Rebello PR, Hale G, Waldmann H, Watson CJ (2009) Alemtuzumab (CAMPATH-1H) for the treatment of acute rejection in kidney transplant recipients: long-term followup. Transplantation 87:1092-1095

49. Kranz B, Kelsch R, Kuwertz-Bröking E, Bröcker V, Wolters HH, Konrad M (2011) Acute antibody-mediated rejection in paediatric renal transplant recipients. Pediatr Nephrol 26:1149-1156

50. Jordan SC, Reinmoen N, Peng A, Lai CH, Cao K, Villicana R, Toyoda M, Kahwaji J, Vo AA (2010) Advances in diagnosing and managing antibody-mediated rejection. Pediatr Nephrol 25:2035-2048

51. Waiser J, Budde K, Schǜtz M (2012) Comparison between bortezomib and rituximab in the treatment of antibody-mediated renal allograft rejection. Nephrol Dial Transplant 27:1246-1251

52. Walsh RC, Brailey P, Girnita A, Alloway RR, Shields AR, Wall GE, Sadaka BH, Cardi M, Tevar A, Govil A, Mogilishetty G, RoyChaudhury P, Woodle ES (2011) Early and late acute antibodymediated rejection differ in immunologically and in response to proteasome inhibition. Transplantation 91:1218-1226

53. Ghirardo G, Benetti E, Poli F, Vidal E, Della Vella M, Cozzi E, Murer L (2014) Plasmapheresis-resistant acute humoral rejection successfully treated with anti-C5 antibody. Pediatr Transplant 18:E1-E5

54. Gonzales-Roncero F, Suner M, Bernal G, Cabello V, Toro M, Pereira P, Angel Gentil M (2012) Eculizumab treatment of acute antibodymediated rejection in renal transplantation: case reports. Transplant Proc 44:2690-2694

55. Kocak B, Arpali E, Demiralp E, Yelken B, Karatas C, Gorcin S, Gorgulu N, Uzunalan M, Turkmen A, Kalayoglu M (2013) Eculizumab for salvage treatment of refractory antibody-mediated rejection in kidney transplant patients: case reports. Transpl Proc 45:1022-1025

56. Billing H, Rieger S, Ovens J, Süsal C, Melk A, Waldherr R, Opelz G, Tönshoff B (2008) Successful treatment of chronic antibody mediated rejection with IVIG and rituximab in pediatric renal transplant recipients. Transplantation $86: 1214-1221$

57. Billing H, Rieger S, Susal C, Waldherr R, Opelz G, Wühl E, Tönshoff B (2012) IVIG and rituximab for treatment of chronic antibody-mediated rejection: a prospective study in paediatric renal transplantion with 2-year follow-up. Transplant Int 25:1165-1173

58. Cicora F, Paz M, Mos F, Roberti J (2013) Use of bortezomib in renal transplant recipients: a single-center experience. Transplant Immunol 29:7-10

59. Opelz G, Daniel V, Naukojat C, Döhler B (2009) Epidemiology of pretransplant EBV and CMV serostatus in relation to posttransplant non-Hodgkin lymphoma. Transplantation 88:962-967

60. Opelz G, Döhner B (2003) Lymphomas after solid organ transplantation: a Collaborative Transplant Study report. Am J Transplant 4: 222-230

61. Kirk A, Cherikh W, Ring M, Burke G, Kaufman D, Knechtle SJ, Potdar S, Shapiro R, Dharnidharka VR, Kauffman HM (2007) Dissociation of depletional induction and post transplant lymphoproliferative disease in kidney recipients treated with alemtuzumAb Am J Transplant 7:2619-2625

62. Dharnidharka VR, Lamb KE, Gregg JA, Meier-Kriesche HU (2012) Associations between EBV serostatus and organ transplant type in PTLD risk: an analysis of the SRTR National Registry Data in the United States. Am J Transplant 12:976-83

63. Puliyanda DP, Stablein DM, Dharnidharka VR (2007) Younger age and antibody induction increase the risk for infection in pediatric renal transplantation: a NAPRTCS report. Am J Transplant 7(3):662666

64. Smith JM, Dhanidharka VR, Talley L, Martz K, McDonald RA (2007) BK virus nephropathy in pediatric renal transplant recipients: an analysis of North American Pediatric Renal Trials and Collaborative Studies (NAPRTCS) registry. Clin J Am Soc Nephrol 2(5):1037-1042

65. Kamar N, Mengelle C, Rostaing L (2009) Incidence of JC-Virus replication after rituximab therapy in solid-organ transplant patients. Am J Transplant 9:244-245

66. Bitzan M, Anselmo M, Carpineta L (2009) Rituximab (B-cell depleting antibody) associated lung injury (RALI): a pediatric case report and systematic review of the literature. Pediatr Pulmonol 44:922-934

\section{Correct answers}

1: c; 2: d; 3: d; 4: b; 5: c 